\title{
TEORI PEMBELAJARAN BAHASA DAN IMPLEMENTASI STRATEGI PEMBELAJARAN AKTIF
}

\author{
Hisyam Zaini \\ Universitas Islam Negeri Sunan Kalijaga \\ Email: hiszaini66@yahoo.com.au
}

\begin{abstract}
Learning language theory and implementation of active learning strategy is expected to show one picture and motivation for the academic community by inviting the learner to actively do or perform any process of learning language based on the theory and strategy of active learning. This method is included in student-centered learning approach or student-centered learning. The author also wants to illustrate the mistaken implications of the implementation of learning strategies and change the paradigm, that language learning is not only a necessary cognitive factor but involves all elements of learning that include the cognitive, physical, mental and emotional aspects. In addition, in the process of language learning it is not enough to rely on one strategy and one method but to use diverse methods and strategies. Because, every method and strategy has their respective advantages
\end{abstract}

Keywords: Active learning, methods, learning strategies

\begin{abstract}
Abstrak
Teori pembelajaran bahasa dan implementasi strategi pembelajaran aktif ini diharapkan mampu menunjukkan satu gambaran dan motivasi bagi civitas akademik dengan mengajak pembelajar untuk secara aktif mengerjakan atau melakukan setiap proses pembelajaran bahasa berdasarkan teori dan strategi pembelajaran aktif. Metode ini masuk dalam pendekatan student-centered learning atau pembelajaran berpusat pada siswa/pembelajar. Penulis juga ingin memberikan gambaran kekeliruan implementasi strategi pembelajaran yang keliru dan merubah paradigma, bahwa pembelajaran bahasa tidak hanya faktor kognitif yang diperlukan tetapi melibatkan semua unsur belajar yang meliputi aspek kognitif, fisik, mental dan juga emosi. Selain itu, dalam proses pembelajaran bahasa tidaklah cukup mengandalakan satu strategi dan satu metode tetapi menggunakan metode dan strategi yang beragam. Karena, setiap metode dan strategi memiliki kelebihan masing-masing.
\end{abstract}

Kata Kunci: Pembelajaran aktif, metode, strategi pembelajaran 


\section{A. Pendahuluan}

Hampir semua penduduk Negara Kesatuan Republik Indonesia adalah bilingual atau dwibahasawan. Artinya adalah bahwa mayoritas penduduk negara Indonesia dapat berbicara dengan dua bahasa, paling tidak adalah bahasa daerah dan bahasa Indonesia. Kondisi ini menunjukkan bahwa mayoritas bangsa Indonesia mempelajari bahasa selain bahasa ibu. Bahasa yang dipelajari oleh setiap anak bangsa adalah bahasa Indonesia yang menjadi bahasa resmi di semua wilayah negara kesatuan republlik Indonesia.

Selain bahasa Indonesia, mayoritas pelajar Indonesia mempelajari bahasa asing, yang bisa dikatakan sebagai bahasa ke tiga. Dalam kurikulum 2013, mata pelajaran Bahasa Indonesia dan Bahasa Inggris masuk dalam mata pelajaran wajib di tingkat pendidikan menengah. Di tingkat perguruan tinggi, bahasa asing juga menjadi mata kuliah wajib dan menjadi mata kuliah inti nasional. Artinya adalah bahwa bahasa asing menjadi mata kuliah yang wajib diambil doleh seluruh mahasiswa di semua perguruan tinggi di Indonesia. Struktur kurikulum yang ada ini menunjukkan bahwa bahasa harus dipelajari di setiap jenjang pendidikan di Indonesia. Dengan demikian belajar bahasa asing, baik sebagai bahasa ke dua atau ke tiga dialami oleh mayoritas pelajar Indonesia.

Problem yang ada di lingkungan perguruan tinggi agama, atau bahkan di sekolah-sekolah keagamaan, khususnya Islam, adalah bahwa bahasa Arab masih dihindari sebagai pembelajar. Bahasa Arab yang sudah dikenalkan kepada anak didik sejak dini, mulai jenjang pendidikan dasar, bahkan tingkat pendidikan taman kanak-kanak, ternyata masih menjadi mata pelajaran yang tidak disenangi atau menjadi 'momok' bagi sebagian dari mereka. Keadaan seperti ini masih terjadi di perguruan tinggi keagamaan Islam. Di PTAIN, seperti STAIN, IAIN, bahkan UIN, masih banyak mahasiswa yang menghindar dari mata kuliah bahasa Arab.

Bagi pendidik atau pengajar bahasa, khususnya bahasa Arab, ketakutan atau keengganan peserta didik mata pelajaran bahasa Arab ini, harus dilihat dari aspek pedagogis. Ada banyak faktor yang mempengaruhi pembalajaran, tidak terkecuali pembelajaran bahasa, di antaranya adalah strategi pembelajaran. Untuk itulah tulsian ini akan mencoba menguraikan strategi-strategi pembelajaran bahasa, dan lebih 
dikhususkan pada strategi-strategi pembelajaran aktif atau yang dikenal dengan sebutan active learning.

\section{B. Pembelajaran Bahasa}

Dalam bahasa Indonesia dikenal istilah belajar dan pembelajaran. Ke dua istilah tersebut telah banyak diterangkan dan didefinisikan oleh para ahli dalam berbagai buku yang menjadi rujukan oleh para ahli yang lain. Dalam KBBI disebutkan bahwa belajar memiliki beberapa makan, yaitu; berusaha memperoleh kepandaian atau ilmu, berlatih, dan berubah tingkah laku atau tanggapan yang disebabkan oleh pengalama. Dalam Longman Dictionary of contemporary English disebutkan bahwa belajar atau to learn adalah to gain knowledge or a subject or skill in an activity, esp through experience or through being taught ${ }^{1}$. Maknanya adalah bahwa belajar adalah (proses) memperoleh pengetahuan, materi, atau ketrampilan dalam sebuah kegiatan, khususnya melalui pengalaman atau pembelajaran.

Para ahli pendidikan telah banyak mendefinisikan belajar, diantaranya adalah sebagai berikut.

1. Menurut Burton belajar adalah suatu perubahan dalam diri individu sebagaihasil interaksinya dengan lingkungannya untukmemenuhi kebutuhan danmenjadikannya lebih mampu melestarikanlingkungannya secara memadai.

2. Menurut Travers belajar mencakup perubahan yangcukup permanen dalam tingkah laku sebagai akibat dari penyingkapan terhadap kondisi dalam lingkungan.

3. Menurut Lefrancois belajar adalah perubahan dalam tingkah laku yang dihasilkan dari pengalaman ${ }^{2}$.

Definisi-definisi yang dikemukakan oleh para ahli pendidikan di atas memiliki benang merah kesamaan. Kata kunci dari definisi-definisi di atas adalah perubahan dan pengalaman. Yang dimaksud dengan perubahan di sini mencakup perubahan tingkah laku, baik kognitif, afektif maupun psikomotorik. Dengan demikian seorang pembelajar yang mengikuti proses pembelajaran di kelas yang memungkinkan dia memperleh pengetahuan atau ketrampilan tertentu dari guru, maka bisa dikatakan bahwa pembelajar tersebut telah belajar. Namun sebaliknya,

\footnotetext{
${ }^{1}$ Longman Distionary of Conttemporary Englsih, 2003, (Essex: Longman), h. 595.

2 Anisah Basleman, Syamsu Mappa, Teori Belajar Orang Dewasa, (Bandung: Rosdakarya, 2011), h. 7-9
} 
meskipun pembelajar mengikuti proses pembelajar, namun tidak memperoleh apa-apa, atau dengan kata lain tidak ada perubahan pada dirinya, baik kognitif, afektif, maupun psikomotorik, maka bisa dikatakan pembelajar (siswa/ mahasiswa) tersebut tidak belajar.

Tidak berbeda dengan istilah belajar, istilah pembelajaran pun memilikii banyakdefinisi yang telah dikemukakan oleh para ahli. Smith berpendapat bahwa kata pembelajaran dapat digunakan untuk menunjuk pada beberapa hal, antara lain adalah; pemerolehan danpenguasaan tentang apa yang telah diketahui mengenai sesuatu; penyuluhan dan penjelasana mengenai arti pengalaman seseorang; atau suatu proses pengujian gagasan yang terorganisasi yang relevan dengan masalah ${ }^{3}$.

Secara tradisional pembelajaran sering diartikan sebagai memindah pengetahuan atau keterampilan. Pembelajaran juga sering diartikan sebagai menyampaikan instruksi, yang dimaksud dengan instruksi di sini adalah padanan dari instruction yang bermakna furnishing others with knowledge and information, especially by a systematic method ${ }^{4}$. Melengkapi seseorang dengan pengetahuan dan informasilainnya, khususnya yang dilakukan dengan metode yang sistematis. Pengertian tentang pembelajaran dengan makna ini mulai dipertanyakan oleh banyak ahli, khususnya pada dekade akhir abad XX. Perubahan pandangan tentang mengajar yang berubah ini menyebabkan pandangan tentang peran guru pun berubah. Para ahli melihat bahwa yang lebih diutamakan dalam pembelajaran adalah bagaimana proses belajar itu terjadi pada pembelajar.

Ramsden mengemukakan tiga teori pembelajaran. Pertama adalah teori yang mengatakan bahwa pembelajaran adalah memindahkan pengetahuan kepada orang lain. Ke dua pembelajaran adalah mengatur kegiatan pembelajar. Ke tiga, pembelajaran adalah membuat pembelajar belajar ${ }^{5}$. Menurut teori pertama, pengajar, guru atau dosen, cukup menyampaikan materi-materi yang harus dikuasai oleh pembelajar. Dengan model ini, pengajar akan beperan dalam pembelajaran secara dominan. Pandangan ke dua memiliki filosofi yang berbeda dari pandangan pertama. Pandangan ke dua ini memandang

\footnotetext{
${ }^{3}$ Ibid., h.12

4 Peter westwood, What teachers need to know about Teaching methods(Victoria: Acer press, , 2008), h. 1.

5 Ramsden, Paul, Learning to Teach in Higher Education (New York: Routledge, 2000), h. 111-116.
} 
bahwa yang terpenting dalam pembelajaran adalah pembelajar terus beraktivitas dalam memeroleh ilmu atau ketrampilan. Adapun teori ke tiga lebih menekankan pada proses belajar pada diri pembelajar. Menurut teori ini, pembelajar harus diberi kesempatan untuk menggunakan segala daya dan kemampuan untuk memperoleh hasil dari proses belajar. Dengan ini, pengajar akan lebih memilihh strategistrategi pembelajarn yang berpusat pada pembelajar atau student-centred learning.

\section{Metode-metode Pembelajaran Bahasa}

Tidak dipungkiri bahwa bahasa, selain bahasa ibu, telah dipelajari oleh manusia semenjak mereka berinteraksi dengan bangsa lain yang memiliki bahasa yang lain pula. Untuk belajar bahasa asing pada masa awal interaksi antar bangsa tidak memerlukan metode khusus yang dipelajari oleh pembelajar bahasa. Mereka belajar bahasa asing langsung dari pemilik bahasa tersebut. Hal ini berbeda dengan kondisi sekarang dimana bahasa asing dipelajari untuk tujuan tertentu dengan cara dan tempat yang tertentu pula. Pembelajaran bahasa yang seperti ini memerlukan guru yang akan membimbing pembelajar dalam mempelajari bahasa tersebut.

Ketika belajar bahasa asing memiliki tujuan yang beragam, maka dibutuhkan metode atau strategi yang memungkinkan guru mengajar dengan efektif. Diyakini bahwa tidak ada satu metode pembelajaran bahasa yang dianggap paling efektif ${ }^{6}$. Anthoni lewat Patel menyatakan bahwa metode adalah strategi khusus yang digunakan untuk mencapai tujuan pembelajaran.

Mackey dalam Patel menyebutkan beberapa metode pembelajaran bahasa, yaitu; Grammar Translation Method, Direct Method, Bilingual method, Reading Method, Situational Method. Grammar Translation Method (GTM) adalah metode pembelajaran bahasa yangsangat kuno. Metode ini mendominasi pembelajaran bahasa di Eropa abad ke IXX sampai abad ke XX. Modifikasi dan pengembangan dari metode ini masih dapat ditemukan saat ini di berbagai belahan dunia.

Dalam GTM bahasa asing dipelajari melalui struktur. Elemenelemen bahasa dipelajari secara detail dengan menggunakan bahasa ibu

6 M.F. Patel, Praveen M. Jain, English Language Teaching, Methods,Tools \& Techniques(Jaipur: Sunrise Publishers \& Distributors, 2008), h. 71. 
sebagai bahasa pengantar. Dalam bahasa Arab, metode ini nampak dengan jelas ketika pembelajaran ditekankan pada $i$ ' $r a b$, yaitu analisis kedudukan suatu kata dalam kalimat. Metode ini banyak disenangi oleh para guru karena mudah diparaktekkan. Dalam pelajaran bahasa Inggris, metode ini digunakan dalam mengajarkan kelas kata, dan frasa.

Beberapa ciri GTM antara lain adalah.

1. Pengajaran difokuskan pada kata, bukan kalimat.

2. Grammar dipandang sebagai unsur terpenting dalam bahasa.

3. Prinsip-prinsip tata bahasa diajarkan secara detail dengan menggunakan bahasa ibu.

4. Tata bahasa diajarkan melalui kaidah, terjemah, dan sering dibandingkan dengan kaidah-kaidah bahasa ibu? ${ }^{7}$.

Meskipun Grammar Translation Method memiliki beberapa kekurangan, namun metode ini memiliki kelebihan yang tidak dimiliki oleh metode lain. Di antara kelebihan-kelebihannya ialah bahwa dengan metode ini, kata atau frasa dari bahasa asing akan lebih mudah dipelajari jika diajarkan dengan cara terjemah.

Metode langsung atau Direct Method adalah metode pembelajaran yang dilakukan secara langsung tanpa harus ada latihanlatihan. Belajar bahasa dengan metode ini digambarkan seperti anak kecil yang baru belajar bicara. Anak kecil belajar bahasa ibu tanpa harus diberi latihan-latihan. Metode ini juga dikenal dengan natural method atau metode alamiah karena anak belajar secara alami ${ }^{8}$. Dalam metode ini pembelajaran bahasa dilakukan dalam lingkungan yang dibentuk sedemikian rupa sehingga menyerupai lingkungan yang ada pada bahasa ke dua atau bahasa asing yang dipelajari. Dengan metode ini guru tidak menggunakan bahasa ibu atau bahasa pembelajar sebagai alat untuk menjelaskan bahasa yang dipelajari. Sebaliknya, guru akan menunjuk objek tertentu yang digunakan untuk menerangkan nomina atau gerakangerakan tertentu untuk menunjukkan verba.

Metode berikutnya adalah bilingual method atau metode dwi bahasa. Metode ini dikatakan sebagai pengembangan dari metode audio visual yang dikembangkan oleh Dodson ${ }^{9}$. Dalam metode ini bahasa ibu digunakan untuk menerangkan kosa kata yang sukar dipahami

7 M.F. Patel, Praveen M. Jain, English Language Teaching, Methods,Tools \& Techniques(Jaipur: Sunrise Publishers \& Distributors, 2008), h. 74.

8 Ibid

9 M.F. Patel, Praveen M. Jain, English Language Teaching, Methods,Tools \& Techniques(Jaipur: Sunrise Publishers \& Distributors, 2008), h. 82. 
pembelajar. Padanan kata asing dalam bahasa ibu dijelaskan untuk memudahkan pemahaman pembelajar. Metode ini cukup efektif digunakan untuk pembelajaran bahasa asing tingkat pemula.

Metode yang lain adalah metode bacaan atau The Reading Method. Metode ini dikembangkan oleh Michael Waste, seorang guru bahasa Inggrisyang bekerja sebagai direktur sekolah bahasa di India ${ }^{10}$. Metode ini dikembangkan di sekolah bahasa Inggris ketika tujuan pembelajarannya adalah untuk mempelajari ilmu pengetahuan dan teknologi. Dalam kondisi seperti ini pemahaman teks lebih dipentingkan daripada berbicara. Oleh sebab itu yang penting dalam metode ini adalah pemahaman teks atau reading comprehension.

Metode terakhir yang dikemukakan oleh Pavel adalah metode situasi atau situation method ${ }^{11}$. Metode ini menekankan pada pemahaman struktur bahasa. Metode ini berkembang pada pertengahan abad ke XX. Metode ini mengajarkan berbagai jenis kalimat yang digunakan untuk situasi tertentu. Dengan ini pembelajar diajari memahami konteks atau situasi kemudian memilih bentuk-bentuk ekspresi dengan kalimat-kalimat tertentu. Dalam bahasa Arab bisa menggunakan bentuk madli atau mudhari', dan dalam bahasa Inggris bisa dipilih present tense, aau past tense dan sebagainya. Oleh sebab itu dalam metode ini kempuan berbicara memperoleh perhatianutama dalam pembelajaran bahasa, sementara tata bahasa atau struktur merupakan elemen penting untuk mengembangkan kemampuan berbicara.

Berbeda dengan Patel, Kumaravadivelu membagi metode pembelajaran bahasa menjadi; language-centered method, learnercentered method dan learning-centered method $^{12}$. Yang dimaksud dengan language-centered method atau metode berpusat pada bahasa adalah bahwa pembelajaran bahasa diajarkan melalui pemahaman bentuk-bentuk lingual. Metode ini, misalnya audiolingual, memberi kesempatan kepada pembelajar untuk mempraktekkan bentuk-bentuk lingual dari bahasa yang dipelajari.

Learner-centered method atau metode berpusat pada siswa lebih melihat pada aspek kebutuhan dan kondisi pembelajar ${ }^{13}$. Dengan metode

\footnotetext{
10 Ibid.,

11 Ibid.,

12 B. Kumaravadivelu, Understanding Language Teaching, From Method to Postmethod (New Jersey: San Jose State University, (New Jersey: Lawrence Erlbaum Associates,Publishers, 2006), h. 90.

${ }_{13} \mathrm{Ibid}$
} 
ini pembelajar diajak untuk melatih kemampuan berbahasa, misalnya untuk tujuan komunikasi. Pembelajar diajak untuk memahami dan menggunakan pola-pola bahasa agar dapat digunakan untuk tujuan-tujuan yang lain.

Metode ke tiga yang dikemukakan oleh Kumaravadivelu adalah learning-centered method, atau metode berpusat pada pembelajaran. Yang dimaksud dengan metode ini adalah metode yang secara prinsip ditekankan pada aspek pembelajaran. Metode ini biasanya dilakukan di kelas dengan memberi latihan-latihan dengan harapan pembelajar dapat menguasai prinsip-prinsip bahasa yang sedang dipelajari ${ }^{14}$.

Metode lain yang tidak kalah terkenal adalah metode yang dikenal dengan pengajaran bahasa komunikatif atau communicative language teaching (CLT). Metode yang dikembangkan pada tahun 70 an ini memiliki dua prinsip utama; pertama, bahasa bukan hanya sekadar pola-pola gramatika dan kosa kata, akan tetapi bahasa memiliki apa yang disebut fungsi ${ }^{15}$. Metode ini berangkat dari teori fungsi bahasa, yaitu sebagai alat komunikasi. Karena itu pembelajaran bahasa harus diarahkan kepada kemampuan berkomunikasi pembelajar. Menurut Chomsky, fokus dari teori bahasa adalah untuk menandai kemampuan pembelajar menggunakan kalimat-kalimat yang secara gramatikal benar dalam suatu bahasa $^{16}$.

Metode ini muncul pada tahun 1960 an di Inggris dan mendapat respon positif dari para ahli, baik dari Inggris sendiri majupun dari Amerika. Metode ini memiliki beberapa prinsip, antara alin adalah sebagai berikut.

1. Pembelajar akan belajar dengan baik jika ia diperlakukan sebagai individu yang memiliki kebutuhan dan minat.

2. Pembelajar akan dapat belajar dengan baik jika ia diberi kesempatan berpartisipasi dalam komunikasi dengan bahasa sasaran.

3. Pembelajar akan belajar dengan baik jika ia menyadari akan perandan hakikat bahasa dan budaya.

\footnotetext{
14 Ibid

15 Jeremy Harmer, The practice of English Language Teaching (Kuala Lumpur : Longman, 2001), h. 50.

16Furqanul Azies, A. Chaedar Alwasilah, Pengajaran Bahasa Komunikatif, (Bandung: Tosdakarya, 1996), h. 16.
} 
4. Pembelajar akan belajar dengan baik jika ia diberi umpan balik yang tepat yang menyangkut kemajuan mereka.

5. Pembelajar akan belajar dengan baik jika ia diberi kesempatan untuk mengatur pembelajarannya sendiri ${ }^{17}$.

Di samping metode-metode yang dikemukakan di atas, masih banyak metode dan teori yang dikemukakan oleh para ahli. Namun karena adanya berbagai keterbatasan sehingga tidak memungkinkan bagi penulis untuk menjelaskan semua metode-metode dan teori-teori tersebut. Meskipun demikian penulis berharap bahwa metode-metode atau teori-teori tersebut di atas dapat memberi gambaran tentang caracara pembelajaran bahasa asing.

\section{Active Learning}

Active learning atau yang sering disebut dalam bahasa Indonesia dengan pembelajaran aktif adalah pembelajaran yang mengajak pembelajar untuk berperan lebih aktif. Dalam pembelajaran ini, mayoritas proses pembelajaran dikendalikan oleh pembelajar. Peran guru lebih banyak sebagai fasilitator. Hal ini dikemukakan oleh Mel Silberman dengan mengatakan when learning is active, students domost of the work. They use their brain... studying ideas, solving problems, and applying what they learn ${ }^{18}$.

Pembelajaran aktif semakin diterima oleh para praktisi pembelajaran karena berubahnya pandangan tentang cara belajar. Secara tradisi, pembelajaran, yang dahulu digunakan istilah pengajaran, sering mengibaratkan pembelajar seperti botol kosong yang siap diisi apa saja oleh guru. Dengan pandangan ini guru secara maksimal memindahkan ilmu kepada pembelajar dengan cara yang mereka kehendaki. Pandangan ini tidak lagi diikuti oleh banyak ahli. Menurut pandangan baru ini, belajar itu melibatkan banyak aspek termasuk melibatkan mental pembelajar. Dalam hal ini Silberman mengatakan: Learning is not an automatic consequence of pouring information into a students's head. It requires the learner's own mental involvement and doing.

Menurut penelitian Dr. Vernon A. Magnesen, seperti dikutip Bobbi de Porter dkk, kita belajar: $10 \%$ dari apa yang kita baca, $20 \%$ dari apa yang kita dengar, $30 \%$ dari apa yang kita lihat, $50 \%$ dari apa

\footnotetext{
${ }^{17}$ Ibid

18 Silberman, Mel, Active Learning, 101 Strategies to Teach Any Subject, (Massasuchetts:
} Allyn \& Bacon,1996), ix. 
yang kita lihat dan dengar, $70 \%$ dari apa yang kita katakan, dan $90 \%$ dari apa yang kita katakan dan lakukan ${ }^{19}$. Penelitian ini menunjukkan bahwa untuk bisa belajar dengan baik, seseorang harus aktif melakukannya. Hal ini ditandai dengan besarnya prosentase yang kita pelajari dari perilaku aktif kita. Dari penelitian di atas dapat diketahui bahwa belajar secara aktif, yaitu dilakukan dengan cara 'mengatakan' dan 'mengatakan' ditambah dengan 'melakukan', akanmemperolehhasil yang maksimal.

Terkait dengan active learning ini, Mel Silberman memberi penjelasan tentang alasan-alasan menggunakan active learning. Dengan mengutip kata-kata bijak dari Confucius, seorang filosof Cina, dia menyatakan ungkapan yang terkenal.

What I hear, I forget. (apa yang saya dengar, saya lupa)

What I see, I rember, (apa yang saya lihat, saya ingat)

What I do, I understand. ( apa yang saya lakukan, saya paham)

Kata-kata bijak Confucius di atas dimodifikasi dengan ungkapan sebagai berikut.

What I hear, I forget.

Apa yang saya dengar, saya lupa.

What I hear and see, I remember a little.

Apa yang saya dengar dan lihat, saya ingat sedikit

What I hear, see, and ask questions about or discuss with someone else, I begin to understand.

Apa yang saya dengar, lihat, dan pertanyakan, atau diskusikan dengan orang lain, saya mulai paham.

What I hear, see, discuss, and do, I acquire knowledge and skill.

Apa yang saya dengar, lihat, dan lakukan, saya memperoleh pengetahuan dan ketrampilan.

What I teach to another, I master.

Apa yang saya ajarkan kepada orang lain, sayamenguasai ${ }^{20}$.

\section{E. Acvtive Learning dalam Pembelajaran Bahasa}

19 Bobbi de Porter, Mark Reardon, Sarah Singer Nourie, Mike, Quantum Teaching, mempraktekkan Quantum Learning di ruang-ruang kelas, terjemah Ary Nilandari (Bandung:Kaifa, 1999), h. 57.

${ }^{20}$ Ibid., h. 1. 
Douglas Brown dalam Principles of language Learning and Teaching mengatakan: Language learning is not a set of easy steps that can be programmed in a quick do-it-yourself kit $^{21}$. Pembelajaran bahasa bukanlah satu langkah mudah yang dapat diprogram seperti mainan rakitan. Ungkapan ini menyiratkan bahwa pembelajaran bahasa bukanlah sebuah kegiatan yang memiliki pakem yang baku. Dari pernyataan ini pula dapat diambil kesimpulan bahwa pembelajaran bahasa tidak bisa mengandalkan satu strategi saja. Dengan kata lain, tidak ada satu strategi pembelajaran bahasa pun yang dikatakan paling baik, paling efektif, paling tepat dan lain sebagainya.

Dalam pernyataan lain Brown menyatakan bahwa: Learning a second language is long and complex undertaking...total commitment, total involvement, a total physical, intellectual, and emotional response are necessary to successfully send and receive messages in a second language ${ }^{22}$. Pembelajaran bahasa ke dua adalah sebuah kegiatan yang panjang dan kompleks...komitmen total, terlibat secara total, respon fisik, intelektual dan emosi yang total diperlukan untuk dapat mengirim dan menerima pesan-pesan dalam bahasa ke dua.

Pernyataan Brown ke dua ini menyarankan bahwa dalam proses pembelajaran, tidak hanya faktor kognitif yang diperlukan. Pembelajaran bahasa ke dua akan berhasil dengan baik jika melibatkan semua unsur belajar yang meliputi aspek kognitif, fisik, mental dan juga emosi. Jika pembelajaran hanya ditekankan pada faktor kognitif, yang diperoleh adalah seperangkat sistem bahasa yang meliputi sistem bunyi, sistem struktur, sistem makna dan lain sebagainya.

Dalam active learning, dijumpai banyak strategi yang melibatkan unsur-unsur yang terlibat dalam proses pembelajaran bahasa. Oleh sebab itu, memilih strategi pembelajaran bukanlah persoalan yang mudah. Pemilihan strategi pembelajaran bahasa memerlukan pemahaman yang lengkap terkait dengan materi, sarana, pembelajar, dan tidak ketinggalan tujuan pembelajaran bahasa yang akan dicapai.

Terkait dengan pemilihan strategi ini Basleman mengemukakan beberapa kriteria pemilihan metode penyajian yang menunjang strategi dan proses interaksi belajar. Kriteria-kriteria tersebut adalah sebagai berikut.

${ }^{21}$ H. Douglas Brown, Teaching by Principles, an Interactive Appproach toLanguage Pedagogy (New York: Longman, 2001), h. 1.

22 Ibid., h. 2. 
1. Metodeyang dipilih sesuai dengan sifat danhakikat tujuan pembelajaran.

2. Metode dipilih sesuai dengan sifat dan hakikat bahan belajar yang disajikan.

3. Metode dipilih sesuai dengan tingkat perkembangan belajar ${ }^{23}$.

Berhubungan dengan pemilihan strategi ini, Brown memberi beberapa petunjuk yang berupa prinsip-prinsip pembelajaran bahasa. Prinsip-prinsip tersebut meliputi hal-hal berikut.

a. Orientation to objectives (berorientasi pada tujuan)

b. Based on problems or needs (berdasar pada problem ataukebutuhan)

c. Understanding vs memorizing (pemahaman vs hafalan)

d. Continum process (proses berkelanjutan)

e. Motivation (motivasi)

f. Learning methods (metode pembelajaran)

g. Factors influencing learning (faktor-faktor yang mempengaruhi

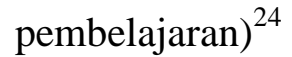

Mel Silberman dan Hisyam Zaini dkk memberi beberapa alternatif strategi pembelajaran aktif yang bisa digunakan untuk materi yang beragam. Beberapa strategi tersebut akan diuraikan di bawah ini disertai dengan penjelasan materi ${ }^{25}$

1. Index Card Match

Strategi ini dapat digunakan untuk pembelajaran bahasa dengan tingkat kesulitan yang beragam, mjulai dari yang sangat sederhana sampai yang kompleks. Langkah-langkah implementasinya di kelas adalah sebagai berikut.

a. Buatlah potongan-potongan kertas sejumlah peserta yang ada di kelas. Jumlah kertas harus ggenap.

b. Bagilah kertas tersebut menjadi dua bagian.

c. Tuliskan satu kata dalam bahasa yang dipelajari, misalnya bahasa Arab, pada setiap kertas yang ada dalam paruh pertama.

d. Pada separuh bagian kertas yang lain dituliskan arti dari setiap kata yang telah ditulis pada separuh kertaas yang pertama.

\footnotetext{
23 Anisah Basleman, Syamsu Mappa , Teori Belajar Orang Dewasa,(Bandung: Rosdakarya, 2011), h. 45.

${ }^{24}$ H. Douglas Brown, Teaching by Principles, an Interactive Appproach toLanguage Pedagogy ................... h. 47.

${ }^{25}$ HisyamZaini,dkk, Strategi Pembelajaran Aktif , (Yogyakarta: CTSD, 2007)
} 
Dengan ini setiap kata yang ditulis pada separuh kertas pertama memiliki arti pada separuh kertas yang lain.

e. Acaklah semua kertas, baik dari separuh pertama atau dari separuh kertas yang ke dua.

f. Bagikan kertas-kertas tersebut kepada semua peserta didik. Dengan langkah ini semua pembelajar menerima satu kertas, sebagian menerima kertas dengan tulisan bahasa Arab dan sebagian menerima kertas dengan tulisan bahasa Indonesia.

g. Mintalah setiap peserta untuk memahami makna dari setiap kata Arab, dan bagi yang menerima kata bahasa Indonesia diminta untuk memikirkan bahasa Arabnya.

h. Guru meminta pembelajar untuk mencari pasangan kertas yang dia miliki.

i. Setelah parfa pembelajar menemjukan pasangan, mereka diminta untuk duduk berdekatan.

j. Guru mengklarifikasi jawaban pembelajar dengan meminta setiap pasangan untuk membacakan kata yang mereke miliki.

Strategi di atas dapat digunakan untuk level pembelajaran yang lebih tinggi. Jika dikehendaki, pada satu bagian kertas ditulisi pertanyaan dan pada bagian kertas yang .lain ditulis jawaban dari setiap pertanyaan yang ditulis pada bagian kertas yang pertama.

\section{Card Sort}

Strategi ini menuntut peserta didik atau pembelajar untuk memiliki pemahaman tentang kategori bahasa yang ada pada kertas yang diterima. Dengan strategi ini pembelajar diminta untuk mencari teman yang memiliki kertas dengan kategori ungkapan yang sama.

Langkah-langkah:

a. Buatlah potongan-potongan kertas sejumlah pembelajar di kelas.

b. Bagilah potongan-potongan kertas tersebut menjadi beberapa kelompokk sesuai dengan kategori kebahasaan yang diinginkan. Misalnya adalah kategori (dalam bahasa Arab); ism, fi'il madli, fi'l mudlari', mashdar, fi'l 'amr, dan lain sebagainya.

c. Pada setiap kelompok kertas ditulis contoh-contoh kata dengan kategori yang telah disebutkan pada nop.2. Jika menginnginkan kategori yang lebih sulit karena lavel belajar yang lebih tinggi dapat menggunakan kategori yanglain. 
Misalnya adalah; jumlah fi'liyah dengan subjek tunggal, subjek dua, atau subjek lebih dari dua dan seterusnya. Dapat juga dipilih kategori jumlah ismiyah dengan kategori mubtada' mu'awwal, mubtada' muakhkhar, jumlah ismiyah dengan kaana dan saudara-saudaranya. Dan lain sebaginya.

d. Pembelajar diminta untuk bergerak keliling kelas untuk mencari atau berkumpul dengan teman-temanyang memiliki kategori bahasa yang sama.

e. Setelah bertemu teman mereka deiminta untuk berkumpul serta bersiap untuk menjelaskan kepada teman-teman kategori bahasa yang ada pada mereka.

f. Jika semua sudah memilliki teman/kelompok, mereka diminta untuk menempel kertas-kertas yang mereka bawa di papan tujlis atau di tempat lain di dalam ruangan.

g. Setiap kelompok diminta untuk menjelaskan kategori bahasa yang mereka mkiliki.

h. Guru memberi klarifikasi dengan menjelaskan materi yang ada.

Jika kategori bahasa yang dipilih adalah level tinggi, pembelajar dipersilahkan untjk menyiapkan presentasi dengan cara melihat buku atau catatan yang mereka miliki. Untuk tujuan ini, guru bisa memberi tahu minggu ebelumnya topik yang akan dipelajari pada pertemuan ini.

3. Broken text (teks acak)

Strategi ini baik digunakan jika tujuan pembelajarannya adalah memahami teks bacaan. Dengan strategi ini, pembelajar diajak untuk memiliki pemahaman yang komprehensif terhadap bacaan, baik dari asepk kosa kata maupun kalimat. Lebih dari itu, mereka juga dituntut untuk memiliki pemahaman terhadap treks bacaan secara keseluruhan.

Langkah-langkah

a. Pilih bacaan yang akan dipelajari.

b. Tulis ulang bacaan tersebut dengan membagi teks bacaan menjadi beberapa bagian.

c. Potong setiap bagian teks sehingga teks menjadi beberapa potongan sesuai dengan pembagian di atas.

d. Bagi kelas menjadi kelompok-kelompok kecil.

e. Setiap kelompok diberi satu teks utuh yang telah dipotong-potong. 
f. Tugas setiap kelompok adalah mengurutkan potongan-potongan bacaan sehingga menjadi bacaan yang lengkap dan urut.

g. Setiap kelompok mempelajari bacaan dari berbagai sisi, baik cara baca maupun maknanya.

h. Setiap kelompok dimintas menerangkan teks tersebut ke kelas.

i. Guru memberi klarifikasi. Klarifikasi dapat berupa penjelasan atau pertanyaan terkait dengan bacaan.

\section{Reading aloud}

Seperti nampak pada namanya, strategi ini juga digunakan untuk mengajarkan teks bacaan. Penekanan pada strategi ini adalah cara baca atau pronunciation dan pemahaman makna.

Langkah-langkah

a. Pilihlah satu teks yang sesuai dengan materi pembelajaran. Usahakanyang menarik untujk dibaca keras di kelas.

b. Berikan kopian teks kepada setiap pembelajar. Beri juga tanda poin-poin atau isu-isu yang menarik untjuk didiskusikan.

c. Bagilah teks menjadi beberapa paragraf atau yang lain.

d. Mintalah beberapa pembelajar, dengan menunjuk orang tertentu, untuk membaca bagian-bagian teks dengan keras.

e. Ketika bacaan sedang berlangsung, berhentilah pada beberapa tempat untuk memberi penekanan arti penting pada poin-poin tertentu. Pada kesempatan ini dapat juga digunakanoleh guru untuk bertanya atau memberi contoh. Jika memungkinkan, pada poin tertentu guru bisa meminta mereka untuk mendiskusikan poin yang ditunjuk.

f. Akhiri sesi pembelajaran dengan memberi klarifikasi atau pertanyaan.

Sebagai variasi dari strategi ini, guru dapat membagi kelas menjadi beberapa kelompok kecil. Masing-masing anggota kelomok secara bergiliran membaqca teks dengan suara yang jelas.

5. True or False

Strategi ini merupakan strategi yang cukup baik digunakan untuk mereview atau untuk mengetahui pemahaman peserta didik terhadap materi yang sudah dipelajari sebelumnya. Meskipun kelihatan sederhana, namun strategi ini menuntut pemahaman yang mendalam terhadap suatu bahasan. Lebih dari itu, strategi ini dapat digunakan untuk jam-jam pelajaran di siang hari, pada saat peserta didik mengalami penurunan semangat, atau 
untuk menghilangkan kantuk. Hal ini terjadi karena strategi ini melibatkan gerakan-gerakan fisik.

Langkah-langkah

a. Buatlah kalimat-kalimat pernyataan yang berisi tentang materi yang akan dipelajari. Kalimat-kalimat tersebut ditulis dengan dua kategori, kalimat yang benar dan kalimat yang salah. Benar dan salah ini bisa dilihat dari segi gramatika atau dari isi jika merujuk pada satu bacaan tertentu.

b. Tuliskan kalimat-kalimat tersebut dalam kertas-kertas, satu kertas satu kalimat.

c. Bagikan kertas-kertas tersebut kepada pembelajar.

d. Setiap pembelajar diminta untuk memahami kalimat yang diterima, baik dari aspek linguistik maupun konten.

e. Guru menjelaskan aturan permainan dalam strategi ini. Pertama, guru membagi ruangan kelas menjadi dua wilayah. Sebelah kanan ruangan adalah tempat berkumpul mereka yang memiliki kalimat yang benar. Sementara wilayah kiri digunakan untuk kalimat-kalimat yang salah.

f. Guru meminta pembelajar membacar pernyataan yang mereka miliki kedmudian bergerak menempati ruangan yang telah diterangkan sesuai dengan penjelasan langkah no.5.

g. Pembelajar yang sudah berkumpul di sisi kiri maupun kanan diberi kesempatan berdiskusi dengan teman-temannya untuk memastikan pilihan mereka.

h. Guru mempersilahkan pembelajar yang akan ;pindah posisi kiri atau kanan.

i. Guru mengklarifikasi jawaban mereka dengan meminta satu per satu untuk membacakan kalimat yang ada di tangannya.

j. Guru melakukan langkah ini sampai waktu yang diinginkan. Sebaiknya semua pembelajar membacakan kalimat mereka.

Jika dilihat secara sepintas, implementasi strategi-strategi aktif, seperti yang dijelaskan di atas nampak seperti permainan atau bahkan main-main. Hal ini bisa dimaklumi karena cara-cara seperti ini mungkin belum dikenal di jenjang-jenjang pendidikan sebelumnya, atau cara-cara seperti ini belum dikenal sama sekali. Memang, prinsip active learning adalah gembira. Dengan metode ini pembelajar diajak untuk belajar tanpa memiliki rasa tertekan. 
Mereka bahkan dengan senang hati akan menikmati proses yang ada dan sekaligus belajar di dalamnya.

Prinsip di atas sesuai dengan hasil penelitian yang dilakukan oleh para ahli. Hasil penelitian mereka menyatakan bahwa belajar akan efektif, jika peserta didik dalam keadaan gembira. Kegembiraan dalam belajar ternyata memberi dampak yang nyata terhadap hasil belajar mereka ${ }^{26}$. Jika pembelajar memperoleh berbagai rangsangan yang menyenangkan dari lingkungan, maka akan terjadi berbagai sentuhan tingkat tinggi pada diri pembelajar yang membuat mereka lebih aktif dan kreatif, baik secara mental maupun fisik ${ }^{27}$. Melalui penelitian juga ditemukan bahwa ketika pembelajar tersenyum atau tertawa, maka aliran darah mereka akan menjadi semakin lancar sehingga terdistribusi ke seluruh anggota tubuh yang membuatnya semakin aktif. Ketika mereka tersenyum, otak mereka menerima suplai darah yang memadai, kondisi seperti ini akan memudahkan mereka berpikir dan memproses informasi. Kesimpulan hasil penelitian mengatakan bahwa semakin senang seseorang terhadap suatu mata pelajaran, maka semakin tinggi pula motivasinya untuk mengikuti pelajaran tersebut. Sebagai konsekuensi adalah semakin baik hasil belajar mereka ${ }^{28}$.

\section{F. Simpulan}

Active learning atau pembelajaran aktif adalah salah satu metode pembelajaran yang mengajak pembelajar untuk secara aktif mengerjakan atau melakukan setiap proses yang ada. Metode ini masuk dalam pendekatan student-centered learning atau pembelajaran berpusat pada siswa/pembelajar. Dalam ranah pembelajaran bahasa, metode harus dipilih dengan lebih cermat karena pembelajaran bahasa memiliki karakteristik yang mungkin hanya dimiliki oleh materi ini. Sebagaimana dikatakan oleh Brown bahwa pembelajaran bahasa tidak bisa disamakan dengan memasang mainan siap pasang yang sudah dijelaskan langkahlangkahnya. Kondisi ini tidak terlepas dari tabiat bahasa itu sendiri. Pembelajaran bahasa tidak bisa dilakukan hanya dengan melibatkan aspek kognitif tanpa menyentuh aspek-aspek yang lain. Keterlibatan

${ }^{26}$ Darmansyah, Strategi Pembelajaran Menyenangkan Dengan Humor(Jakarta : Bumi Aksara, 2011), h.3.

27 Ibid.,

28 Ibid., 
seluruh indra sangat diperlukan dalam pembelajaran bahasa. Hal ini disebabkan oleh fungsi bahasa sebagai alat komunikasi. Meskipun demikian, pemilihan metode pembelajaran bahasa harus disesuaikan dengan tujuan dari pembelajaran itu sendiri. Jika tujuan pembelajaran bahasa adalah untuk dapat berkomunikasi dengan bahasa tersebut, maka metode yang dipillih akan berbeda dari metode pembelajaran dengan tujuan pemahaman teks misalnya. Namun demikian, dalam pembelajaran bahasa perlu diupayakan strategi yang membuat pembelajar senang dan gembira. Semoga bermanfaat.

\section{DAFTAR PUSTAKA}

Anisah Basleman, Syamsu Mappa, 2011, Teori Belajar Orang Dewasa, (Bandung: Rosdakarya)

B. Kumaravadivelu, 2006, Understanding Language Teaching, From Method to Postmethod (New Jersey: San Jose State University, (New Jersey: Lawrence Erlbaum Associates,Publishers)

Bobbi de Porter, Mark Reardon, Sarah Singer Nourie, Mike,1999, Quantum Teaching, mempraktekkan Quantum Learning di ruang-ruang kelas, terjemah Ary Nilandari (Bandung:Kaifa)

Darmansyah,2011, Strategi Pembelajaran Menyenangkan Dengan Humor (Jakarta : Bumi Aksara)

Diane Larsen-Freeman, 1986, Techniques and Principles in Language Teaching (Oxford: Oxford University Press)

Furqanul Azies, A. Chaedar Alwasilah, 1996, Pengajaran Bahasa Komunikatif,(Bandung: Tosdakarya)

Douglas Brown, 2001, Teaching by Principles, an Interactive Appproach toLanguage Pedagogy (New York: Longman)

(New York: Longman

Hasan Alwi, 2003, Kamus Besar Bahasa Indonesia, (Jakarta: Balai Pustaka)

HisyamZaini,dkk, 2007, Strategi Pembelajaran Aktif, (Yogyakarta: CTSD) 
Jeremy Harmer,2001, The practice of English Language Teaching (Kuala Lumpur : Longman)

, (2007), How to Teach English, (Ediburg: Pearson Education Limited)Longman Distionary of Conttemporary Englsih, 2003, (Essex: Longman)

M.F. Patel, Praveen M. Jain, 2008, English Language Teaching, Methods,Tools\&Techniques(Jaipur: Sunrise Publishers \& Distributors)

Ramsden, Paul, 2000, Learning to Teach in Higher Education (New York: Routledge)

Peter westwood, 2008, What teachers need to know about Teaching methods (Victoria: Acer press)

Robin M Gilles, Adrian M Ashman, 2003, Co-operative Learning, The social and intellectual outcomes of learning in groups, (London:Routledge)

Silberman, Mel, Active Learning, 101 Strategies to Teach Any Subject, (Massasuchetts: Allyn \& Bacon,1996) 